\title{
Creatinine-Based Glomerular Filtration Rates and Microalbuminuria for Detecting Metabolic Abnormalities in US Adults: The National Health and Nutrition Examination Survey 2003-2004
}

\author{
Robert N. Foley ${ }^{a, b} \quad$ Changchun Wang ${ }^{a}$ Areef Ishani ${ }^{a, b}$ Hassan N. Ibrahim ${ }^{b}$ \\ Allan J. Collins ${ }^{a, b}$

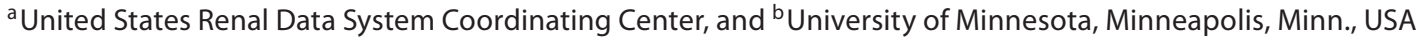

\section{Key Words}

Chronic kidney disease $\cdot$ Creatinine $\cdot$ Glomerular filtration rate $\cdot$ Microalbuminuria
A policy of searching for metabolic complications in every adult with low GFR or microalbuminuria has limited diagnostic yield.

Copyright $\odot 2007$ S. Karger AG, Basel

\begin{abstract}
Background/Aims: Guidelines suggest searching for metabolic complications of chronic kidney disease when glomerular filtration rates (GFR) or urinary albumin tests are abnormal. This study aimed to quantify diagnostic test characteristics of these measures for detecting metabolic abnormalities. Methods: Subjects were participants aged $\geq 20$ years $(n=7,778)$ in the US National Health and Nutrition Examination Survey 2003-2004. Low GFR was defined as creatinine-based estimate $<60 \mathrm{ml} / \mathrm{min}$ per $1.73 \mathrm{~m}^{2}$; abnormal urinary albumin-creatinine ratio as $\geq 20 \mathrm{mg} / \mathrm{dl}$ in men, $\geq 30$ $\mathrm{mg} / \mathrm{dl}$ in women; and metabolic abnormalities as abnormal potassium, hemoglobin, bicarbonate, phosphorus, or parathyroid hormone levels. Results: Of adults, 5.66\% had low GFR and $8.14 \%$ abnormal urinary albumin-creatinine ratio. Overall, $15.09 \%$ had $\geq$ one metabolic abnormality, as did $34.07 \%$ with low GFR ( $<0.0001)$ and $24.27 \%$ with abnormal urinary albumin-creatinine ratio $(p=0.0021)$. Considered as a diagnostic test, the sensitivity, specificity, and positive and negative predictive values of low GFR for detecting $\geq 1$ metabolic abnormality were $0.13,0.96,0.34$, and 0.86 , respectively. Corresponding values for abnormal urinary albumincreatinine ratio were $0.13,0.92,0.24$, and 0.86 . Conclusions:
\end{abstract}

\section{KARGER}

() 2007 S. Karger AG, Basel

Fax +41 613061234

E-Mail karger@karger.ch

www.karger.com

\section{Introduction}

Chronic kidney disease (CKD) is a sizeable public health problem in the United States [1-4]. It appears to be common, and dose-dependent relationships between disease burden and cardiovascular disease and death have been observed $[1,5-10]$. Several national guidelines recommend the use of creatinine-based glomerular filtration rate (GFR) estimates and urinary albumin excretion tests for early identification of potentially progressive CKD. GFR levels below $60 \mathrm{ml} / \mathrm{min}$ per $1.73 \mathrm{~m}^{2}$ represent a major threshold in these guidelines [2, 11, 12]. This value is used increasingly as a basis for further investigation for individuals found to have CKD. For example, the US National Kidney Foundation Kidney Disease Outcome Quality Initiative (K/DOQI) clinical practice guidelines for bone metabolism and disease recommend measuring calcium, phosphorus, and parathyroid hormone (PTH) in all subjects with GFR below $60 \mathrm{ml} / \mathrm{min}$ per $1.73 \mathrm{~m}^{2}$ [13]; similar recommendations for anemia testing appear in corresponding anemia management guidelines [14].

Robert N. Foley, MB

United States Renal Data System

914 South 8th Street, Suite S-253

Minneapolis, MN 55404 (USA)

Tel. +1 612347 5979, Fax +1 612347 5878, E-Mail rfoley@usrds.org 
Strategies leading to early identification of treatable metabolic abnormalities would be useful from a public health perspective, as these often come to light late in the course of progressive CKD. One intuitive hypothesis is that the criteria used to define high risk of progressive CKD or cardiovascular disease (such as GFR below 60 $\mathrm{ml} / \mathrm{min}$ per $1.73 \mathrm{~m}^{2}$ or abnormal urinary albu min excretion rates) are also useful for early identification of these treatable abnormalities. The utility of such an approach, however, is not well understood. Hence, the major objectives of this national study were to estimate the diagnostic test characteristics of creatinine-based GFR thresholds and abnormal urinary albumin-creatinine ratios for detecting classic metabolic abnormalities of CKD (hyperkalemia, anemia, metabolic acidosis, hyperphosphatemia, and hyperparathyroidism) that might lead to changes in clinical management.

\section{Materials and Methods}

\section{Objectives}

Our major objectives were to quantify diagnostic test characteristics for detecting abnormal levels of metabolic parameters among community-dwelling adults in the US of the following commonly used criteria:

(1) Creatinine-based estimated GFR $<60 \mathrm{ml} / \mathrm{min}$ per $1.73 \mathrm{~m}^{2}$

(2) Random, untimed ('spot'), urinary albumin-creatinine levels $\geq 20 \mathrm{mg} / \mathrm{dl}$ in $\mathrm{men}$, and $\geq 30 \mathrm{mg} / \mathrm{dl}$ in women.

\section{Design}

The National Health and Nutrition Examination Survey (NHANES), which became an annual survey in 1998, releases public-use data files every 2 years. The current study examined NHANES participants aged 20 years and older in 2003 to 2004. NHANES uses stratified, multistage, probability sampling methods to assemble a nationwide probability sample representative of the noninstitutionalized population of the US [15].

\section{Measurements and Definitions}

Detailed technical descriptions of the laboratory methods are available at the NHANES web site [15]. The kinetic alkaline picrate Jaffe rate method was used for creatinine measurement. The Centers for Disease Control recently indicated that creatinine values from NHANES do not require a calibration factor to align them to gold-standard methods [16]. A solid-phase fluorescent immunoassay was used to measure urinary albumin. Intact parathyroid hormone levels were measured on an Elecsys 1010 analyzer with a coefficient of variation $<5 \%$ at all times. Calcium values were adjusted for possible hypoalbuminemia as follows: adjusted calcium $(\mathrm{mg} / \mathrm{dl})=$ calcium $(\mathrm{mg} / \mathrm{dl})+0.8[4-$ serum albumin (mg/dl)].

Estimated GFR levels were derived from the Modification of Diet in Renal Disease formula, namely $175 \times$ (serum creatinine value $)^{-1.154} \times$ age $^{-0.203} \times(0.742$ for women $) \times(1.21$ if AfricanAmerican) [17]. The GFR categories chosen were those suggested by the K/DOQI Clinical Practice Guidelines for Chronic Kidney Disease: Evaluation, Classification, and Stratification [2] with the exception that GFR below $15 \mathrm{ml} / \mathrm{min}$ per $1.73 \mathrm{~m}^{2}$ was not considered a separate category because of small numbers. Regarding diagnostic test characteristics, a GFR threshold of $60 \mathrm{ml} / \mathrm{min}$ per $1.73 \mathrm{~m}^{2}$ was the primary analytical focus, because this value defines the presence of CKD, and because it is used as a threshold before systematic evaluation of metabolic complications of CKD.

Urinary albumin-creatinine ratios were classified using the system suggested by de Jong and Curhan [18], which incorporates the observation that levels are typically higher in communitydwelling women than in men [19]: normal, $<10 \mathrm{mg} / \mathrm{dl}$ in men, $<15$ in women; high normal, $10 \mathrm{mg} / \mathrm{dl}$ to $<20$ in men, $15 \mathrm{mg} / \mathrm{dl}$ to $<30$ in women; microalbuminuria, $20 \mathrm{mg} / \mathrm{dl}$ to $<200 \mathrm{in} \mathrm{men,} 30 \mathrm{mg} / \mathrm{dl}$ to $<300$ in women; macroalbuminuria, $\geq 200 \mathrm{mg} / \mathrm{dl}$ in men, $\geq 300$ in women. Findings were similar when values $\geq 30$ were used to define abnormality and these findings are not presented here.

The defining values for metabolic complications (based on common clinical usage for potassium and bicarbonate, and $\mathrm{K} /$ DOQI guidelines $[13,14]$ for hemoglobin, calcium, phosphorus, and PTH) were as follows: potassium $\geq 5.0 \mathrm{mmol} / \mathrm{l}$, hemoglobin $<11.0 \mathrm{~g} / \mathrm{dl}$, bicarbonate $<20.0 \mathrm{mmol} / \mathrm{l}$, phosphorus $>4.6 \mathrm{mg} / \mathrm{dl}$, and parathyroid hormone $>70.0 \mathrm{pg} / \mathrm{ml}$.

Diagnostic tests of abnormal kidney function were repeated in segments of the general population for whom CKD screening is recommended, including those with self-reported diabetes mellitus or hypertension and those aged 50 years or more $[18,20]$. Another high-risk group was defined by the presence of self-reported diabetes mellitus, self-reported hypertension, family history of diabetes mellitus, or family history of hypertension, criteria mirroring those used in the US National Kidney Foundation Kidney Early Evaluation Program [21].

\section{Analysis}

National parameter estimates were produced by adjusting for the sampling weights of complex survey designs, using SUDAAN software (Research Triangle Institute, Research Triangle Park, N.C., USA) for complex sample surveys. SAS Version 8.2 (SAS Institute, Inc., Cary, N.C., USA) was used for data assembly.

As an example of the use of GFR thresholds as diagnostic tests for metabolic abnormalities, consider the following, applying GFR $<60 \mathrm{ml} / \mathrm{min}$ per $1.73 \mathrm{~m}^{2}$ to potassium levels $\geq 5.0 \mathrm{mmol} / \mathrm{l}$. The true-positive population has GFR $<60$ and potassium $\geq 5.0$; false-positives have GFR $<60$ and potassium $<5.0$; true-negatives have GFR $\geq 60$ and potassium $<5.0$; and false-negatives have GFR $\geq 60$ and potassium $\geq 5.0$. While SUDAAN allows $95 \%$ CIs for false-positive ratios and true-positive ratios to be calculated for discrete GFR values, confidence intervals for area under the receiver operating characteristic (ROC) curve cannot be generated when GFR is treated as a continuous variable. Thus, GFR thresholds were systematically lowered from 100 to 30, in 5-unit increments, and area under the ROC curve for detection of $\geq 1$ metabolic abnormalities was calculated based on point estimates for sensitivity and specificity; a similar approach was applied to urinary albumin-creatinine levels dichotomized by the thresholds used to define normal, high normal, microalbuminuria, and macroalbuminuria. 
Table 1. Population characteristics $(n=7,778)$

\begin{tabular}{|c|c|}
\hline Characteristics & Mean or $\%(95 \% \mathrm{CI})$ \\
\hline \multicolumn{2}{|l|}{ Glomerular filtration rate, $\mathrm{ml} / \mathrm{min}$ per $1.73 \mathrm{~m}^{2}$} \\
\hline$>90 \%$ & $40.22(36.57,43.98)$ \\
\hline $60-89 \%$ & $54.13(50.69,57.53)$ \\
\hline $30-59 \%$ & $5.35(4.17,6.83)$ \\
\hline$<30 \%$ & $0.31(0.21,0.44)$ \\
\hline \multicolumn{2}{|l|}{ Urinary albumin-creatinine ratio, $\%$ a, 1} \\
\hline Normal & $82.25(79.70,84.55)$ \\
\hline High normal & $9.60(8.38,10.97)$ \\
\hline Microalbuminuria & $7.29(5.90,8.99)$ \\
\hline Macroalbuminuria & $0.85(0.56,1.30)$ \\
\hline \multicolumn{2}{|l|}{ Glomerular filtration rate $<60$ or micro- } \\
\hline albuminuria or macroalbuminuria, $\%^{1}$ & $12.41(10.61,14.46)$ \\
\hline Serum creatinine, $\mathrm{mg} / \mathrm{dl}$ & $0.90(0.89,0.92)$ \\
\hline Age, years & $42.91(41.62,44.20)$ \\
\hline \multicolumn{2}{|l|}{ Sex } \\
\hline Male, \% & $51.27(49.33,53.21)$ \\
\hline Female, $\%$ & $48.73(46.79,50.67)$ \\
\hline \multicolumn{2}{|l|}{ Race-ethnicity } \\
\hline White, \% & $75.56(68.56,81.75)$ \\
\hline African-American, $\%$ & $10.22(7.04,14.61)$ \\
\hline Hispanic American, \% & $10.11(6.81,14.76)$ \\
\hline Other, $\%$ & $3.91(2.56,5.91)$ \\
\hline High risk for chronic kidney disease & $71.71(68.29,74.89)$ \\
\hline Self-reported diabetes mellitus, \% & $5.54(4.50,6.81)$ \\
\hline Self-reported hypertension, $\%$ & $24.79(22.21,27.56)$ \\
\hline Family history of diabetes mellitus, \% & $50.11(46.46,53.75)$ \\
\hline Family history of hypertension, $\%$ & $32.79(30.03,35.67)$ \\
\hline Body mass index 2 & $27.75(27.30,28.20)$ \\
\hline \multicolumn{2}{|l|}{ Metabolic abnormalities } \\
\hline$\geq 1$ abnormality, $\%^{3}$ & $15.09(13.01,17.44)$ \\
\hline Potassium $\geq 5.0 \mathrm{mmol} / 1, \%{ }^{4}$ & $0.93(0.61,1.41)$ \\
\hline Hemoglobin $<11.0 \mathrm{~g} / \mathrm{dl}, \%^{5}$ & $0.81(0.59,1.10)$ \\
\hline Bicarbonate $<20 \mathrm{mmol} / \mathrm{l}, \%$ & $1.33(0.75,2.34)$ \\
\hline Phosphorus $>4.6 \mathrm{mg} / \mathrm{dl}, \%^{4}$ & $5.73(4.86,6.75)$ \\
\hline Parathyroid hormone $>70 \mathrm{pg} / \mathrm{ml}, \%^{6}$ & $7.94(6.41,9.80)$ \\
\hline
\end{tabular}

a Classification of urinary albumin-creatinine ratio $(\mathrm{mg} / \mathrm{dl})$ : normal, $<10$ in men, $<15$ in women; high normal, 10 to $<20$ in men, 15 to $<30$ in women; microalbuminuria, 20 to $<200$ in men, 30 to $<300$ in women; macroalbuminuria, $\geq 200$ in men, $\geq 300$ in women.

${ }^{1}$ Data missing for $1.5 \%$ of the sample. ${ }^{2}$ Data missing for $1.6 \%$ of the sample. ${ }^{3}$ Data missing for $0.07 \%$ of the sample. ${ }^{4}$ Data missing for $0.04 \%$ of the sample. ${ }^{5}$ Data missing for $0.01 \%$ of the sample. ${ }^{6}$ Data missing for $0.12 \%$ of the sample.

\section{Results}

Of the 7,778 study subjects, $40.22 \%$ had GFR $\geq 90 \mathrm{ml} /$ min per $1.73 \mathrm{~m}^{2}, 54.13 \%$ between 60 and $89,5.35 \%$ between 30 and 59 , and $0.31 \%<30 \mathrm{ml} / \mathrm{min}$ per $1.73 \mathrm{~m}^{2}$ (table 1). Microalbuminuria was present in $7.29 \%$ of sub-

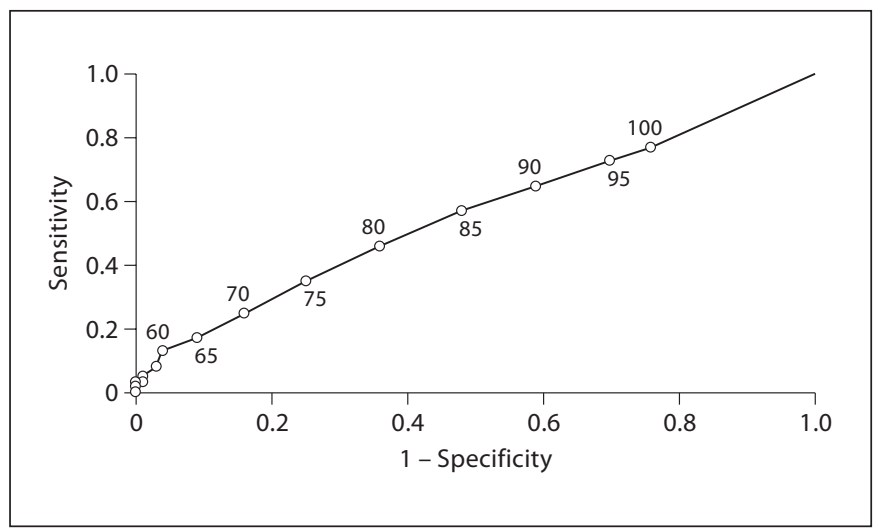

Fig. 1. ROC curve for detecting $\geq 1$ metabolic complication with glomerular filtration rate thresholds between 30 and $100 \mathrm{ml} / \mathrm{min}$ per $1.73 \mathrm{~m}^{2}$. The area under the curve is 0.56 .

jects and macroalbuminuria in $0.85 \%$. High phosphorus and PTH levels were the most common individual metabolic abnormalities, and $15.09 \%$ of subjects had at least one metabolic abnormality typical of CKD.

The prevalence estimate for at least one metabolic abnormality among subjects with normal kidney function was $13.95 \%$; for GFR $<60 \mathrm{ml} / \mathrm{min}$ per $1.73 \mathrm{~m}^{2}, 34.07 \%$ ( $\mathrm{p}<0.0001)$, for abnormal albumin-creatinine ratio, $24.27 \%(\mathrm{p}=0.0021)$; and for either GFR $<60 \mathrm{ml} / \mathrm{min}$ per $1.73 \mathrm{~m}^{2}$ or abnormal albumin-creatinine ratio, $25.57 \%$ $(\mathrm{p}=0.0003)$ (table 2). Multivariate analysis showed that corresponding adjusted odds ratios were $1,3.16(\mathrm{p}<$ $0.0001), 1.74(\mathrm{p}=0.0068)$, and $2.09(\mathrm{p}=0.0010)$.

The sensitivity, specificity, positive predictive value, and negative predictive value of GFR $<60 \mathrm{ml} / \mathrm{min}$ per $1.73 \mathrm{~m}^{2}$ for detecting $\geq 1$ metabolic abnormality were $0.13,0.96,0.34$, and 0.86 , respectively (table 3 ). Figure 1 shows the ROC curve for detecting $\geq 1$ metabolic abnormality with threshold GFR values varying from 30 to 100 $\mathrm{ml} / \mathrm{min}$ per $1.73 \mathrm{~m}^{2}$, in 5 -unit increments. The point estimate for area under the curve was 0.56 .

The sensitivity, specificity, positive predictive value, and negative predictive value of abnormal albumin-creatinine ratios values for detecting $\geq 1$ metabolic abnormality were $0.13,0.92,0.24$, and 0.86 , respectively (table 3). Figure 2 shows the corresponding ROC curve for high-normal, microalbuminuria, and macroalbuminuria thresholds. The point estimate for area under the curve was 0.56 .

Diagnostic test characteristics of GFR $<60 \mathrm{ml} / \mathrm{min}$ per $1.73 \mathrm{~m}^{2}$ and abnormal albumin-creatinine ratio values 
Table 2. Metabolic abnormalities, compared by category of estimated glomerular filtration rate and urinary albumin-creatinine ratio

\begin{tabular}{|c|c|c|c|c|c|c|}
\hline \multirow[t]{2}{*}{ Comparisons } & \multicolumn{6}{|c|}{ Metabolic abnormalities } \\
\hline & $\geq 1$ & $\begin{array}{l}\text { potassium } \\
\geq 5.0 \mathrm{mmol} / 1\end{array}$ & $\begin{array}{l}\text { hemoglobin } \\
<11 \mathrm{~g} / \mathrm{dl}\end{array}$ & $\begin{array}{l}\text { bicarbonate } \\
<20 \mathrm{mmol} / \mathrm{l}\end{array}$ & $\begin{array}{l}\text { phosphorus } \\
>4.6 \mathrm{mg} / \mathrm{dl}\end{array}$ & $\begin{array}{l}\text { PTH } \\
>70 \mathrm{pg} / \mathrm{ml}\end{array}$ \\
\hline \multicolumn{7}{|l|}{ Percentage (95\% CI) } \\
\hline GFR $\geq 60$ & $13.95(11.88,16.33)$ & $0.68(0.41,1.12)$ & $0.69(0.49,0.96)$ & $1.35(0.77,2.37)$ & $5.51(4.61,6.57)$ & $6.97(5.55,8.72)$ \\
\hline GFR $<60$ & $34.07(26.57,42.45)$ & $5.01(3.08,8.06)$ & $2.80(1.69,4.59)$ & $1.03(0.46,2.30)$ & $9.35(5.86,14.61)$ & $24.27(17.79,32.20)$ \\
\hline p value* & $<0.0001$ & 0.0075 & 0.0053 & 0.2868 & 0.0745 & $<0.0001$ \\
\hline $\mathrm{ACR}<20 \mathrm{M} / 30 \mathrm{~F}$ & $14.01(11.90,16.43)$ & $0.82(0.49,1.36)$ & $0.70(0.51,0.96)$ & $1.21(0.60,2.43)$ & $5.55(4.50,6.83)$ & $7.12(5.68,8.91)$ \\
\hline $\mathrm{ACR} \geq 20 \mathrm{M} / 30 \mathrm{~F}$ & $24.27(18.80,30.72)$ & $1.28(0.68,2.42)$ & $1.71(0.89,3.26)$ & $1.24(0.26,5.65)$ & $7.77(4.14,14.14)$ & $15.32(11.26,20.49)$ \\
\hline p value* & 0.0021 & 0.3046 & 0.0467 & 0.9791 & 0.3957 & 0.0010 \\
\hline \multicolumn{7}{|l|}{ GFR $\geq 60$ and } \\
\hline \multicolumn{7}{|l|}{ GFR $<60$ or } \\
\hline $\mathrm{ACR} \geq 20 \mathrm{M} / 30 \mathrm{~F}$ & $25.57(20.52,31.38)$ & 2.29 & $1.64(0.96,2.80)$ & $1.05(0.31,3.53)$ & $7.95(4.85,12.77)$ & $15.94(12.24,20.49)$ \\
\hline p value $e^{*}$ & 0.0003 & 0.0376 & 0.0228 & 0.8005 & 0.2509 & 0.0001 \\
\hline \multicolumn{7}{|c|}{ Adjusted odds ratio** (95\% CI) } \\
\hline GFR $\geq 60$ & 1 (reference) & 1 (reference) & 1 (reference) & 1 (reference) & 1 (reference) & 1 (reference) \\
\hline GFR $<60$ & $3.16(2.09,4.77)$ & $2.04(0.82,5.07)$ & $2.49(0.74,8.38)$ & $2.60(1.24,5.44)$ & $2.62(1.39,4.93)$ & $4.26(2.60,6.98)$ \\
\hline$p$ value ${ }^{* *}$ & $<0.0001$ & 0.1138 & 0.1291 & 0.0150 & 0.0054 & $<0.0001$ \\
\hline $\mathrm{ACR}<20 \mathrm{M} / 30 \mathrm{~F}$ & 1 (reference) & 1 (reference) & 1 (reference) & 1 (reference) & 1 (reference) & 1 (reference) \\
\hline $\mathrm{ACR} \geq 20 \mathrm{M} / 30 \mathrm{~F}$ & $1.74(1.19,2.54)$ & $0.69(0.35,1.38)$ & $1.67(0.80,3.50)$ & $1.45(0.22,9.56)$ & $1.42(0.59,3.41)$ & $1.91(1.34,2.71)$ \\
\hline$p$ value ${ }^{* *}$ & 0.0068 & 0.2723 & 0.1589 & 0.6824 & 0.4109 & 0.0014 \\
\hline \multicolumn{7}{|l|}{ GFR $\geq 60$ and } \\
\hline $\mathrm{ACR}<20 \mathrm{M} / 30 \mathrm{~F}$ & 1 (reference) & 1 (reference) & 1 (reference) & 1 (reference) & 1 (reference) & 1 (reference) \\
\hline$A C R \geq 20 \mathrm{M} / 30 \mathrm{~F}$ & $2.09(1.42,3.08)$ & $1.20(0.58,2.49)$ & $1.78(0.81,3.92)$ & $1.46(0.31,6.94)$ & $1.73(0.74,4.00)$ & $2.31(1.65,3.22)$ \\
\hline$p$ value $e^{* *}$ & 0.0010 & 0.6011 & 0.1417 & 0.6087 & 0.1865 & 0.0001 \\
\hline
\end{tabular}

$\mathrm{ACR}=$ Urinary albumin-creatinine ratio $(\mathrm{mg} / \mathrm{dl}) ; \mathrm{GFR}=$ glomerular filtration rate $\left(\mathrm{ml} / \mathrm{min}\right.$ per $\left.1.73 \mathrm{~m}^{2}\right) ; \mathrm{PTH}=$ parathyroid hormone; $20 \mathrm{M} / 30 \mathrm{~F}$, ACR $20 \mathrm{mg} / \mathrm{dl}$ in males, 30 in females.

* The $\chi^{2}$ test was used for between-group comparisons. ** With logistic regression; metabolic abnormalities (yes or no) were the outcome variables. Adjustment was made for age, sex, race, body mass index, self-reported diabetes mellitus and self-reported hypertension.

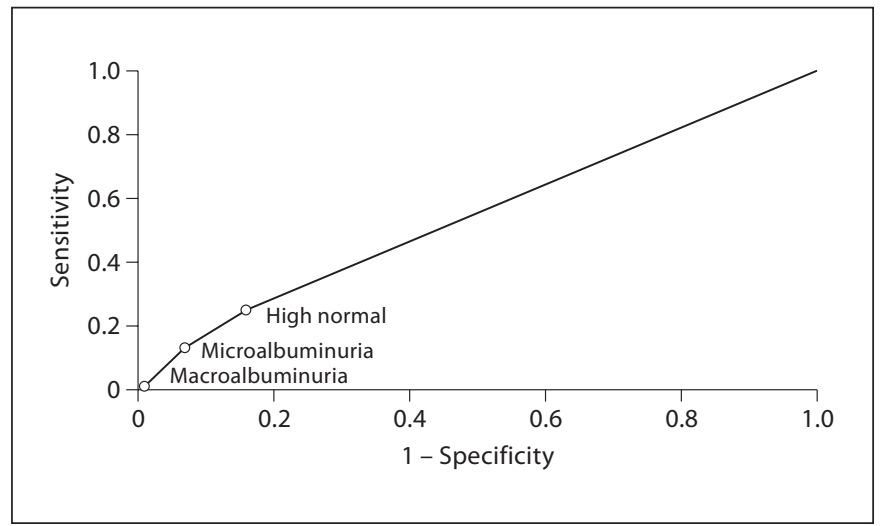

Fig. 2. ROC curve for detecting $\geq 1$ metabolic complication with different urinary albumin-creatinine ratio thresholds. Classification of urinary albumin-creatinine ratio (mg/dl): normal, $<10$ in men, $<15$ in women; high normal, 10 to $<20$ in men, 15 to $<30$ in women; microalbuminuria, 20 to $<200$ in men, 30 to $<300$ in women; macroalbuminuria, $\geq 200$ in men, $\geq 300$ in women. The area under the curve is 0.56 .

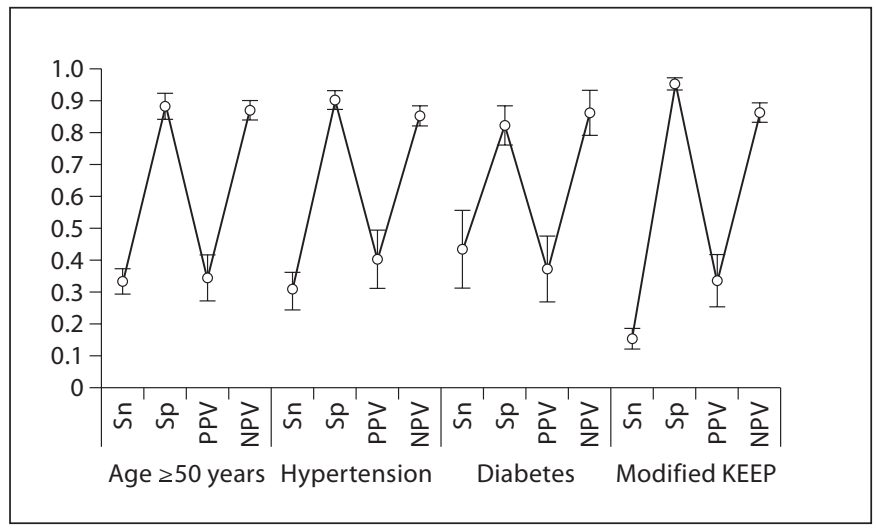

Fig. 3. Diagnostic test characteristics of glomerular filtration rate $<60 \mathrm{ml} / \mathrm{min}$ per $1.73 \mathrm{~m}^{2}$ for detecting $\geq 1$ metabolic in specific subsets of the general population, point estimates and $95 \%$ confidence intervals. KEEP = Kidney Early Evaluation Program; $\mathrm{NPV}=$ negative predictive value; $\mathrm{PPV}=$ positive predictive value; $\mathrm{Sn}=$ sensitivity; $\mathrm{Sp}=$ specificity. 
Table 3. Diagnostic test characteristics of GFR $<60 \mathrm{ml} / \mathrm{min}$ per $1.73 \mathrm{~m}^{2}$ and abnormal albumin-creatinine ratio for identifying metabolic abnormalities

\begin{tabular}{|c|c|c|c|c|c|c|}
\hline \multirow[t]{2}{*}{ Characteristics } & \multicolumn{6}{|c|}{ Metabolic abnormalities } \\
\hline & $\geq 1$ & $\begin{array}{l}\text { potassium } \\
\geq 5.0 \mathrm{mmol} / \mathrm{l}\end{array}$ & $\begin{array}{l}\text { hemoglobin } \\
<11 \mathrm{~g} / \mathrm{dl}\end{array}$ & $\begin{array}{l}\text { bicarbonate } \\
<20 \mathrm{mmol} / \mathrm{l}\end{array}$ & $\begin{array}{l}\text { phosphorus } \\
>4.6 \mathrm{mg} / \mathrm{dl}\end{array}$ & $\begin{array}{l}\text { PTH } \\
>70 \mathrm{pg} / \mathrm{ml}\end{array}$ \\
\hline \multicolumn{7}{|l|}{ GFR $<60$} \\
\hline Sensitivity & $0.13(0.10,0.16)$ & $0.31(0.16,0.45)$ & $0.20(0.10,0.29)$ & $0.04(0.02,0.06)$ & $0.09(0.05,0.13)$ & $0.17(0.13,0.21)$ \\
\hline Specificity & $0.96(0.94,0.97)$ & $0.95(0.93,0.96)$ & $0.94(0.93,0.96)$ & $0.94(0.93,0.96)$ & $0.95(0.93,0.96)$ & $0.95(0.94,0.97)$ \\
\hline PPV & $0.34(0.26,0.42)$ & $0.05(0.03,0.07)$ & $0.03(0.01,0.04)$ & $0.01(0.00,0.02)$ & $0.09(0.05,0.14)$ & $0.24(0.17,0.31)$ \\
\hline NPV & $0.86(0.84,0.88)$ & $0.99(0.99,1.00)$ & $0.99(0.99,1.00)$ & $0.99(0.98,0.99)$ & $0.94(0.93,0.95)$ & $0.93(0.91,0.95)$ \\
\hline \multicolumn{7}{|c|}{$\mathrm{ACR} \geq 20 \mathrm{M} / 30 \mathrm{~F}$} \\
\hline Sensitivity & $0.13(0.09,0.17)$ & $0.11(0.03,0.19)$ & $0.17(0.08,0.26)$ & $0.07(-0.04,0.19)$ & $0.11(0.03,0.19)$ & $0.16(0.11,0.20)$ \\
\hline Specificity & $0.92(0.90,0.93)$ & $0.91(0.89,0.92)$ & $0.91(0.89,0.92)$ & $0.91(0.89,0.93)$ & $0.91(0.89,0.92)$ & $0.91(0.90,0.93)$ \\
\hline PPV & $0.24(0.18,0.30)$ & $0.01(0.00,0.02)$ & $0.02(0.01,0.03)$ & $0.01(-0.01,0.03)$ & $0.08(0.03,0.13)$ & $0.15(0.11,0.20)$ \\
\hline NPV & $0.86(0.84,0.88)$ & $0.99(0.99,1.00)$ & $0.99(0.99,1.00)$ & $0.99(0.98,1.00)$ & $0.94(0.93,0.96)$ & $0.93(0.91,0.94)$ \\
\hline \multicolumn{7}{|c|}{$\mathrm{GFR}<60$ or $\mathrm{ACR} \geq 20 \mathrm{M} / 30 \mathrm{~F}$} \\
\hline Sensitivity & $0.21(0.16,0.26)$ & $0.30(0.14,0.47)$ & $0.25(0.14,0.36)$ & $0.10(-0.02,0.21)$ & $0.17(0.08,0.26)$ & $0.25(0.20,0.30)$ \\
\hline Specificity & $0.88(0.86,0.90)$ & $0.87(0.85,0.89)$ & $0.87(0.85,0.89)$ & $0.87(0.84,0.89)$ & $0.87(0.85,0.89)$ & $0.88(0.86,0.90)$ \\
\hline PPV & $0.31(0.23,0.39)$ & $0.04(0.02,0.06)$ & $0.02(0.01,0.04)$ & $0.01(0.00,0.02)$ & $0.08(0.04,0.13)$ & $0.22(0.15,0.28)$ \\
\hline NPV & $0.79(0.77,0.82)$ & $0.91(0.89,0.93)$ & $0.91(0.89,0.93)$ & $0.91(0.89,0.92)$ & $0.87(0.85,0.88)$ & $0.85(0.84,0.87)$ \\
\hline
\end{tabular}

$\mathrm{ACR}=$ Urinary albumin-creatinine ratio $(\mathrm{mg} / \mathrm{dl}) ; \mathrm{GFR}=$ glomerular filtration rate $\left(\mathrm{ml} / \mathrm{min}\right.$ per $\left.1.73 \mathrm{~m}^{2}\right) ; \mathrm{NPV}=$ negative predictive value; $\mathrm{PPV}=$ positive predictive value; $\mathrm{PTH}$ = parathyroid hormone; $20 \mathrm{M} / 30 \mathrm{~F}, \mathrm{ACR} 20 \mathrm{mg} / \mathrm{dl}$ in males, 30 in females. Values are percentages (95\% CIs).

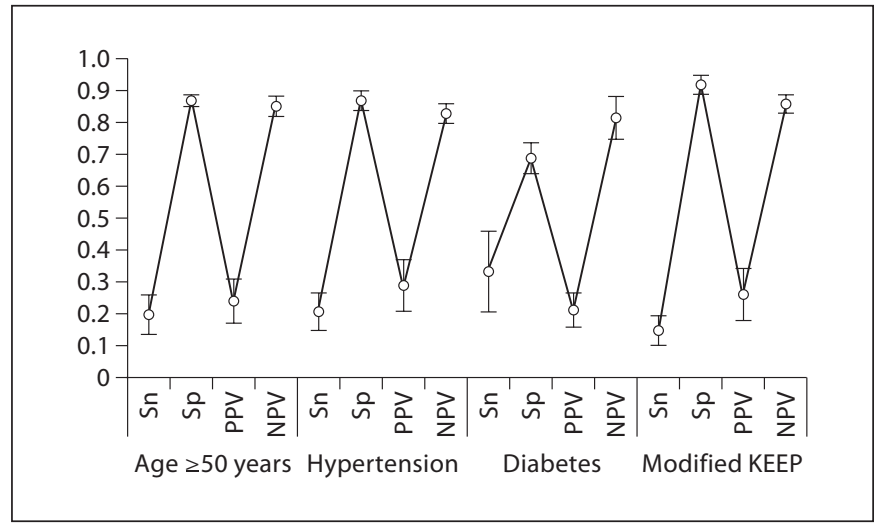

Fig. 4. Diagnostic test characteristics of urinary albumin-creatinine ratio $\geq 20 \mathrm{mg} / \mathrm{dl}$ in males and $\geq 30 \mathrm{mg} / \mathrm{dl}$ in females for detecting $\geq 1$ metabolic abnormality in specific subsets of the general population, point estimates and $95 \%$ CIs. KEEP $=$ Kidney Early Evaluation Program; NPV = negative predictive value; $\mathrm{PPV}=$ positive predictive value; $\mathrm{Sn}=$ sensitivity; $\mathrm{Sp}=$ specificity.

for detecting $\geq 1$ metabolic abnormality in predefined segments of the population are shown in figures 3 and 4 . Findings within these population segments mirrored those of the overall population.

Creatinine-Based GFR and Metabolic Abnormalities

\section{Discussion}

We found statistically significant associations between declining GFR, rising albumin-creatinine ratio, and the prevalence of metabolic abnormalities. However, as diagnostic tests, creatinine-based GFR estimates and abnormal urinary albumin-creatinine ratios were relatively insensitive for detecting any of the metabolic abnormalities that might lead to treatment changes in subjects with CKD. Specificity values, in contrast, were high. Hence, it would seem, from a population perspective, that measuring GFR levels may be useful because 'normal' levels rule out the presence of metabolic abnormalities. However, if 'low' GFR values are the sole criterion that determines further testing, diagnostic yields are likely to be disappointing. If detection of these treatable metabolic abnormalities is a public health policy, then more efficient strategies may be required.

Few national, community-based studies have examined the relationship between GFR levels and metabolic complications of CKD, with the exception of anemia. Regarding the latter, one study examined participants in NHANES III (1988 to 1994) and reported that anemia prevalence (hemoglobin level $<12 \mathrm{~g} / \mathrm{dl}$ in men and $<11$ $\mathrm{g} / \mathrm{dl}$ in women) increased from $1 \%$ with estimated GFR $60 \mathrm{ml} / \mathrm{min}$ per $1.73 \mathrm{~m}^{2}$, to $9 \%$ with GFR 30 , and $33 \%$ with GFR $15 \mathrm{ml} / \mathrm{min}$ per $1.73 \mathrm{~m}^{2}$ [22]. These findings largely 
paralleled the anemia-GFR relationships in our study, and added a clear statistical association to a widely held clinical impression. Demonstrating statistical associations like these may be very important for answering important biological questions, such as 'How early in the evolution of CKD does anemia develop?' They may not, however, address other important questions such as the usefulness of hemoglobin screening in CKD patients or the numbers of anemic subjects identified and missed if GFR $<60 \mathrm{ml} / \mathrm{min}$ per $1.73 \mathrm{~m}^{2}$ is the criterion for anemia testing.

Screening for diseases and clinical abnormalities is dependent on many factors including the availability of an accurate screening test. The utility of a diagnostic test is also heavily dependent on the underlying prevalence of the disease in the population being studied, and low- and high-prevalence states are beset, respectively, by falsepositive and false-negative diagnostic tests. Noteworthy in our study, given that GFR of $60 \mathrm{ml} / \mathrm{min}$ per $1.73 \mathrm{~m}^{2}$ is a major decision point in most guidelines, is that prevalence of any metabolic abnormality was $14.52 \%$ in subjects with GFR levels between 60 and $89 \mathrm{ml} / \mathrm{min}$ per $1.73 \mathrm{~m}^{2}$, and $31.45 \%$ in those with GFR levels between 30 and $60 \mathrm{ml} / \mathrm{min}$ per $1.73 \mathrm{~m}^{2}$.

We would like to highlight the limitations of this study. Because it was a cross-sectional study, longitudinal mea- sures were not available. Reflecting clinical reality, goldstandard GFR measures such as inulin and isotope clearance methods were not available. In addition, because the precision and accuracy of creatinine-based GFR estimates for detecting a truly abnormal GFR may be limited, misclassification bias may be partly responsible for the findings of this study. Similarly, assessing the utility of non-creatinine-based tests of GFR, such as cystatin, would be desirable [23]. In spite of its limitations, we believe that this study provides useful information. The study design, which is representative of contemporary adults in the US, allows classic relationships between kidney function and metabolic complications to be described systematically in a community setting. It suggests that current strategies for identification of CKD complications may not be optimal.

\section{Acknowledgments}

This study was performed as a deliverable under Contract No. HHSN267200715002C (National Institute of Diabetes and Digestive and Kidney Diseases, National Institutes of Health, Bethesda, Md., USA). The authors thank United States Renal Data System colleagues Beth Forrest for manuscript preparation and Nan Booth, MSW, MPH, for manuscript editing.

\section{References}

-1 Coresh J, Byrd-Holt D, Astor BC, Briggs JP, Eggers PW, Lacher DA, Hostetter TH: Chronic kidney disease awareness, prevalence, and trends among US adults, 1999 to 2000. J Am Soc Nephrol 2003;16:180-188.

2 National Kidney Foundation: K/DOQI clinical practice guidelines for chronic kidney disease: evaluation, classification, and stratification. Am J Kidney Dis 2002;39(suppl 1): S1-S266.

-3 Coresh J, Astor BC, Greene T, Eknoyan G, Levey AS: Prevalence of chronic kidney disease and decreased kidney function in the adult US population: third National Health and Nutrition Examination Survey. Am J Kidney Dis 2003;41:1-12.

$\checkmark 4$ Levey AS, Coresh J, Balk E, Kausz AT, Levin A, Steffes MW, Hogg RJ, Perrone RD, Lau J, Eknoyan G: National Kidney Foundation practice guidelines for chronic kidney disease: evaluation, classification, and stratification. Ann Intern Med 2003;139:137-147.
5 Fried LF, Shlipak MG, Crump C, Bleyer AJ, Gottdiener JS, Kronmal RA, Kuller LH, Newman AB: Renal insufficiency as a predictor of cardiovascular outcomes and mortality in elderly individuals. J Am Coll Cardiol 2003;41:1364-1372.

6 Henry RM, Kostense PJ, Bos G, Dekker JM, Nijpels G, Heine RJ, Lex M, Bouter LM, Stehouwer CDA: Mild renal insufficiency is associated with increased cardiovascular mortality: The Hoorn Study. Kidney Int 2002;62: 1402-1407.

7 Muntner P, He J, Hamm L, Loria C, Whelton PK: Renal insufficiency and subsequent death resulting from cardiovascular disease in the United States. J Am Soc Nephrol 2002; 13:745-753.

8 Anavekar NS, McMurray JJ, Velazquez EJ, Solomon SD, Kober L, Rouleau J-L, White HD, Nordlander R, Maggioni A, Dickstein K, Zelenkofske S, Leimberger JD, Califf RM, Pfeffer MA: Relation between renal dysfunction and cardiovascular outcomes after myocardial infarction. N Engl J Med 2004;351: 1285-1295.
-9 Go AS, Chertow GM, Fan D, McCulloch CE, Hsu CY: Chronic kidney disease and the risks of death, cardiovascular events, and hospitalization. N Engl J Med 2004;351: 1296-1305

10 Stevens LA, Coresh J, Greene T, Levey AS: Assessing kidney function-measured and estimated glomerular filtration rate. N Engl J Med 2006;354:2473-2483.

11 Joint Specialty Committee on Renal Medicine of the Royal College of Physicians and the Renal Association, and the Royal College of General Practitioners: Chronic Kidney Disease in Adults: UK Guidelines for Identification, Management and Referral. London, Royal College of Physicians, 2006.

12 Johnson D, Caring for Australians with Renal Impairment (CARI): The CARI guidelines: evaluation of renal function. Nephrology 2005;10(suppl 4):S133-S176.

13 National Kidney Foundation: K/DOQI Clinical Practice Guidelines for Bone Metabolism and Disease in Chronic Kidney Disease, 2003. Available at: http://www.kidney.org/ professionals/kdoqi/guidelines_bone/ Guide1.htm Accessed July 24, 2007. 
14 National Kidney Foundation: K/DOQI Clinical Practice Guidelines and Clinical Practice Recommendations for Anemia in Chronic Kidney Disease, 2006. Available at: http://www.kidney.org/professionals/kdoqi/guidelines_anemia/guide2.htm\#cpr11 Accessed July 24, 2007.

15 Centers for Disease Control and Prevention: National Center for Health Statistics, National Health and Nutrition Examination Survey. Available at: http://www.cdc.gov/ nchs/nhanes.htm Accessed July 24, 2007.

16 Centers for Disease Control and Prevention: National Center for Health Statistics, National Health and Nutrition Examination Survey. Available at: http://www.cdc.gov/ nchs/data/nhanes/nhanes_03_04/general_ $\% 20$ note_for_serum_creatinine.pdf Accessed July 24, 2007
7 Levey AS, Coresh J, Greene T, Stevens LA, Zhang Y, Hendriksen S, Kusek JW, Van Lente F, Chronic Kidney Disease Epidemiology Collaboration: Using standardized serum creatinine values in the modification of diet in renal disease study equation for estimating glomerular filtration rate. Ann Intern Med 2006;145:247-254.

18 de Jong PE, Curhan GC: Screening, monitoring, and treatment of albuminuria: public health perspectives. J Am Soc Nephrol 2006; 17:2120-2126

19 Mattix HJ, Hsu CY, Shaykevich S, Curhan G: Use of the albumin/creatinine ratio to detect microalbuminuria: implications of sex and race. J Am Soc Nephrol 2002;13:1034-1039.
20 Molitch ME, DeFronzo RA, Franz MJ, Keane WF, Mogensen CE, Parving H-H, Steffes MW: American Diabetes Association: nephropathy in diabetes. Diabetes Care 2004; 27(suppl 1):S79-S83.

21 National Kidney Foundation: Kidney Early Evaluation Program, 2007. Available at: http://www.kidney.org/news/keep/KEEPabout.cfm Accessed July 24, 2007.

22 Astor BC, Muntner P, Levin A, Eustace JA, Coresh J: Association of kidney function with anemia: the Third National Health and Nutrition Examination Survey (1988-1994). Arch Intern Med 2002;162:1401-1408.

23 Grubb A, Simonsen O, Sturfelt G, Truedsson L, Thysell H: Serum concentration of cystatin C, factor D and beta 2-microglobulin as a measure of glomerular filtration rate. Acta Med Scand 1985;218:499-503. 